\title{
COMPARISON OF THE EFFECTS OF MASSIVE BLOOD TRANSFUSIONS AND OF LIVER EXTRACT IN PERNICIOUS ANEMIA 1
}

\author{
By CHARLES S. DAVIDSON, JOHN C. MURPHY, R. JANET WATSON, AND \\ W. B. CASTLE \\ (From the Thorndike Memorial Laboratory, Second and Fourth Medical Services (Harvard), \\ Boston City Hospital and the Department of Medicine, Harvard Medical School, Boston)
}

(Received for publication July 10, 1946)

The features of the classical, clinical and hematological response to the administration of liver (1) and of stomach (2) preparations, and recently of synthetic $L$. casei factor $(3,4)$ in patients with untreated pernicious anemia, are well known. The action of these therapeutic agents is, however, sometimes rather carelessly regarded as one of direct stimulation of blood production. It is perhaps more accurate to consider that liver extract acts by the replacement of a nutritional deficiency and so, in one way or another, permits effective response of the bone marrow to the stimulus of the anoxia common to all anemias. Moreover, despite an obvious analogy with the effects of iron administration in patients with hypochromic (iron deficiency) anemia, the concept that liver extract therapy in pernicious anemia also acts by abolishing a maturation arrest leading to decreased blood production has recently been challenged ( 5 to 7 ). This represents a return to the older viewpoint that the anemia is based on excessive blood destruction, manifest especially by the increased output of bile pigments in the feces. Under this hypothesis, the nutritional deficiency is assumed in some way to permit the advent of a hemolytic process (7), and the absence of elevated reticulocyte counts in the peripheral blood is explained on the hypothesis that these cells are destroyed selectively before they leave the bone marrow (5). The megaloblastic hyperplasia of that organ is thus interpreted as an unusually severe degree of the erythroid cell immaturity seen in the bone marrows of severe hemolytic anemias in animals $(8)$ and in man $(9,10)$. It appeared to be desirable to secure, if possible, additional information on some of these points of view, and to attempt to distinguish between the direct effects of liver extract therapy and those due to elevations

1 The expenses of this investigation were defrayed in part by grants from the J. K. Lilly Gift to the Harvard Medical School. in hemoglobin levels following its use. Accordingly, observations were made of the comparative hematological and clinical effects of rapidly repeated transfusions, and of the administration of liver extract in pernicious anemia.

\section{METHODS}

Five patients with classical Addisonian pernicious anemia in relapse were selected, and were given daily transfusions of whole blood or red cell concentrates until, in 2 , the red cell counts reached 3 million per $\mathrm{cu} . \mathrm{mm}$., and in 3 , the red cell counts reached 5 million per $\mathrm{cm}$. $\mathrm{mm}$. Liver extract was then administered to the 2 patients with red cell counts of 3 million per cu. mm., and to 2 of the 3 patients with 5 million red cells per cu, $\mathrm{mm}$. The remaining patient with a normal red cell value was given no further therapy for 46 days, when his red cell count had fallen to 3 million per cu. $\mathrm{mm}$. Liver extract was then administered. Both during the period of transfusion, and after liver extract administration, the changes in clinical condition were observed, as well as changes in red cell count, hemoglobin concentration, corpuscular indices, reticulocytes, white cell and platelet counts, and icterus index. Sternal marrow puncture and biopsy were performed at appropriate times in order to determine the comparative effects on the marrow cytology of the red cell transfusions, and of the administration of liver extract.

The blood cell counts were made on oxalated venous blood with U. S. Bureau of Standards pipettes and counting chambers. The hemoglobin was determined using the Klett-Summerson colorimeter, using 15.6 grams of hemoglobin per $100 \mathrm{ml}$. of blood as the standard. The red cell indices were obtained by the method of Wintrobe (11). Blood platelet counts were performed by a modification of the method of Rees and Ecker (12). The icterus index was determined by comparing plasma with dichromate standards (13). Bone marrow puncture was made in the mid-sternum at the level of the second interspace, using the needle designed by Turkel (14). Sternal marrow biopsies were done by the surgical service, using a 1/4-inch trephine and standard surgical technique.

Whole blood for transfusions was collected in sodium citrate solution by the hospital blood bank. Red cell concentrates were prepared by centrifuging fresh citrated blood and withdrawing most of the plasma. A small amount of saline (50 to $75 \mathrm{ml}$.) was added and well 
mixed with the cells before infusion. Cell concentrates were used before they were more than 3 days old.

\section{RESULTS}

(a) Red blood cell values and indices.

During the period of transfusions, there was a rapid rise of the red cell count, hemoglobin concentration and hematocrit.

Case No. 1 received the red cell equivalent of $9,750 \mathrm{ml}$. of blood, $7,900 \mathrm{ml}$. of which were necessary to bring the red cell values to normal in 13 days. Case No. 2 received the red cell equivalent of $6,500 \mathrm{ml}$. of blood, all as red cell concentrates, bringing the red cell values to normal in 7 days. Cases No. 3 and No. 4 received the red cell equivalent of $3,000 \mathrm{ml}$. of blood in 3 days, with a resultant red cell count of about 3 million per cu. $\mathrm{mm}$. Cases No. 5 received the red cell equivalent of $8,000 \mathrm{ml}$. of whole blood in 8 days, resulting in an essentially normal red cell value.

(b) Reticulocytes.

During the period of blood transfusions there was no significant rise in the reticulocyte count in any of the patients.

In the 2 patients given multiple U.S.P. units of liver extract by intramuscular injections immedi-

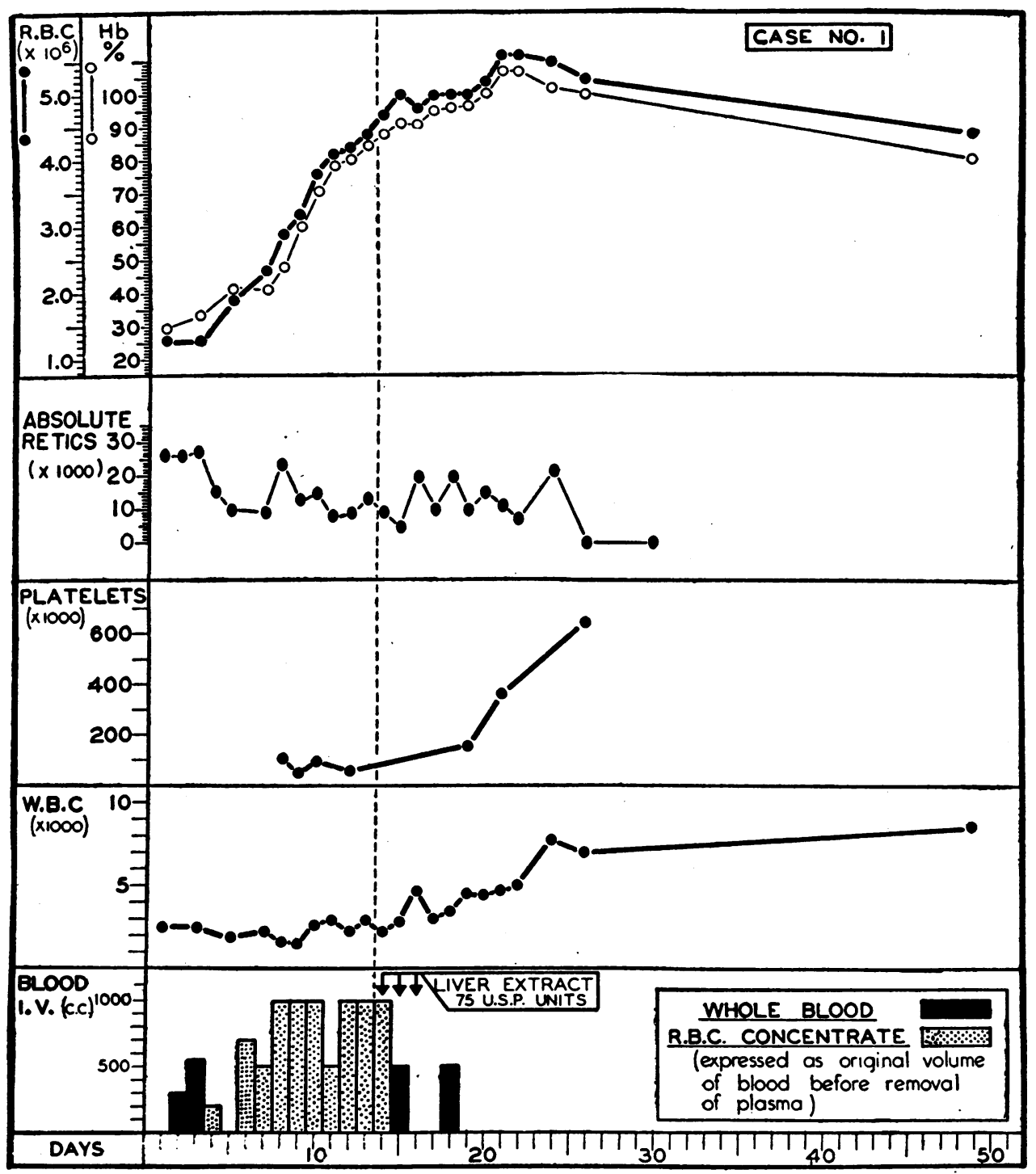

Fig. 1. Case No. 1 
ately after the end of the series of transfusions when their red cell values were normal, no rise in reticulocytes occurred in Case No. 1 (Figure 1), and only a slight rise, reaching 60,000 per cu. $\mathrm{mm}$., in Case No. 2. The peak of this response was on the 7th day after liver extract was first injected, and after the red cell count had fallen to about 4 million per cu. mm. (Figure 2).

The 3 patients given liver extract when their red cell counts were near 3 million per cu. $\mathrm{mm}$.

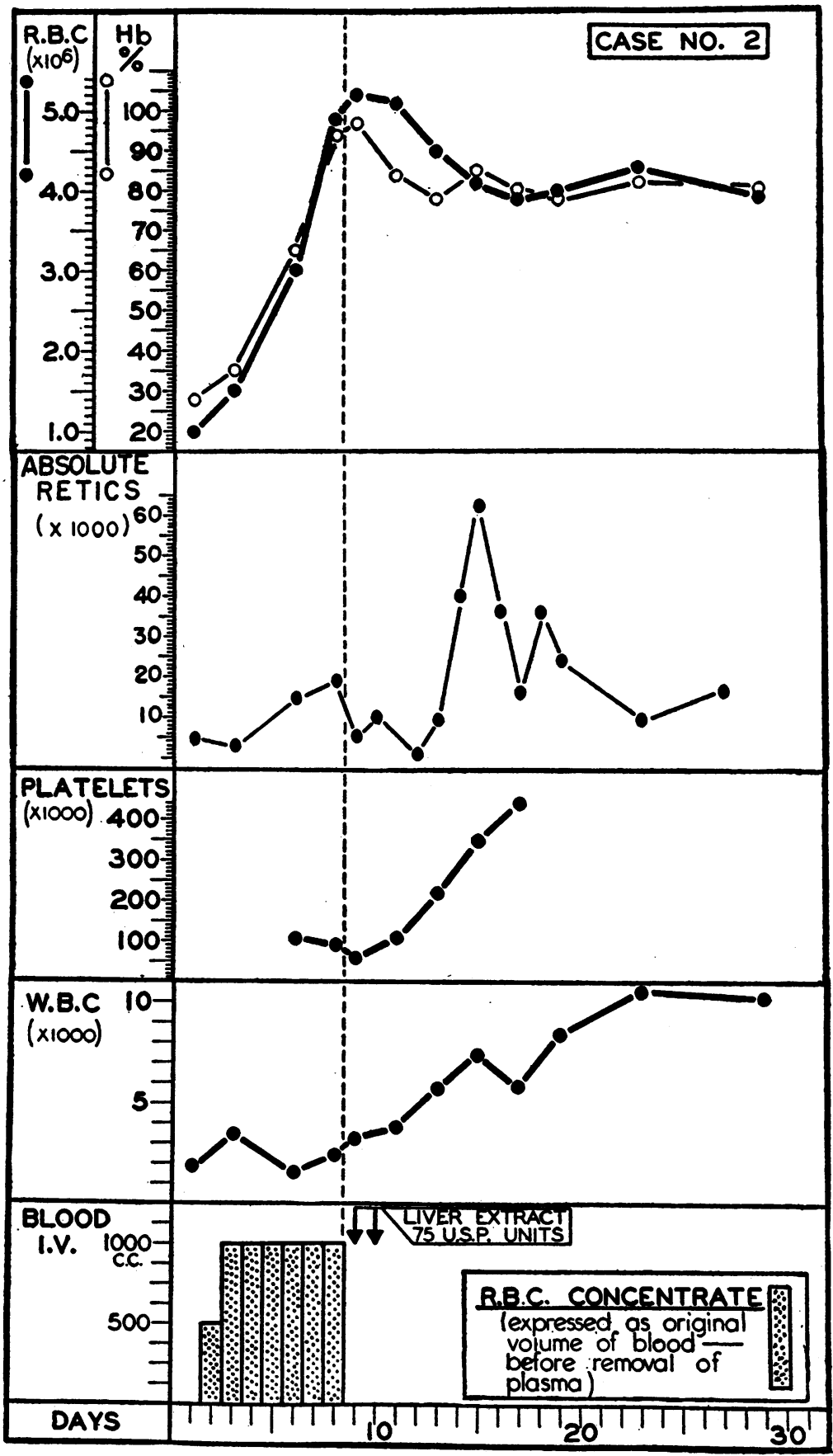

Fig. 2. Case No. 2 


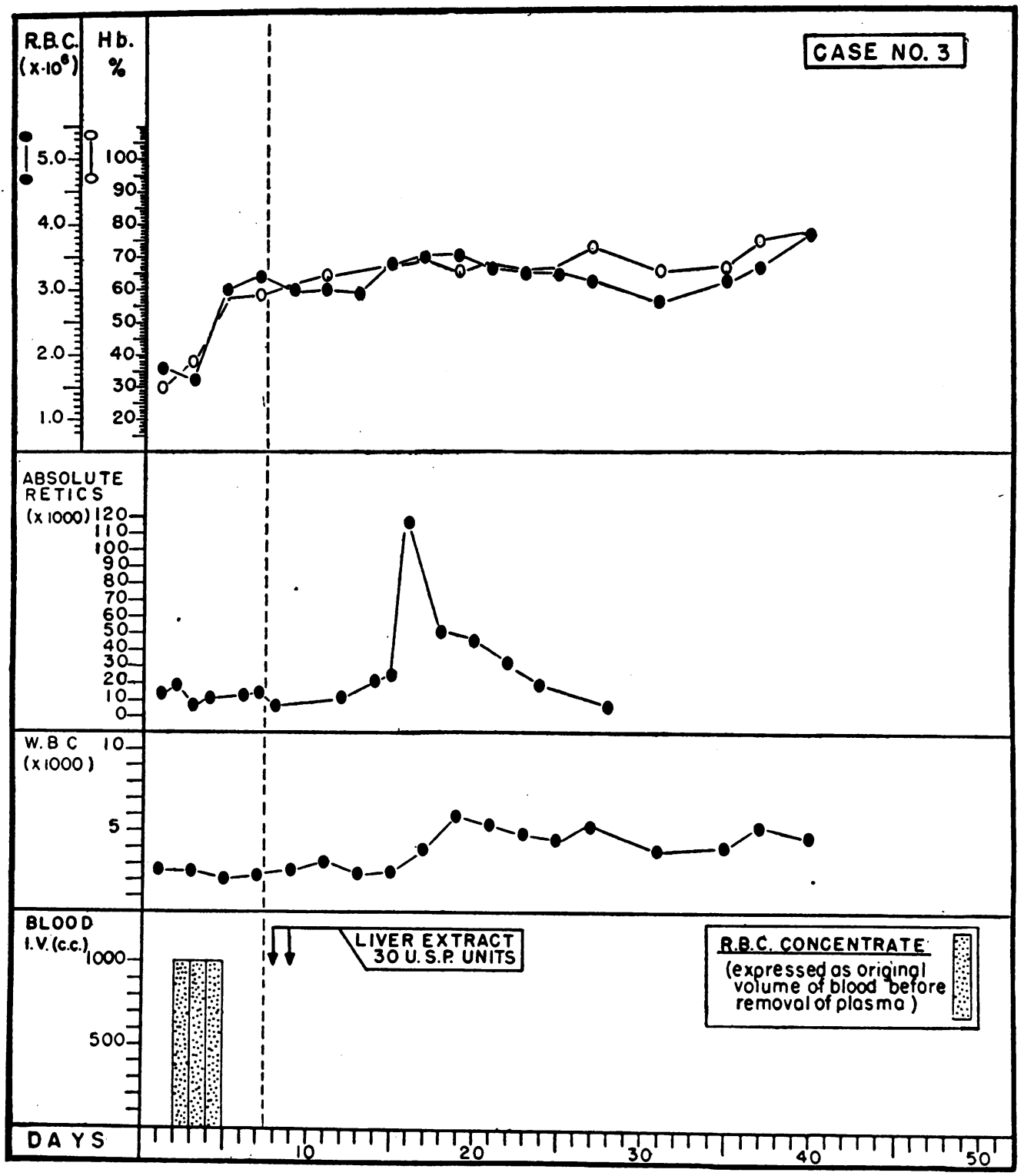

Fig. 3. CASE No. 3

had rises in reticulocyte counts reaching maxima of $123,000,116,000$ and 326,000 per cu. mm., respectively, in Cases Nos. 3, 4, and 5.

(c) White blood cells and platelets.

Leukopenia was present in all patients before and during the period of blood transfusions. In fact, it was only after the administration of liver extract that a significant rise in the white cell count occurred. That this rise was not due to a delayed response to previous transfusions is made clear by the observations in Case No. 5 (Figure 5), in which a period of 55 days separates the transfusions from the administration of liver extract.

Thrombocytopenia was still evident during the transfusions in the 4 patients in whom platelet counts were made. Here again, it is evident that no significant rise in blood platelets occurred until after liver extract was administered. This is particularly well shown in Cases Nos. 1, 2, and 5 (Figures 1, 2, 5), and is suggested in Case No. 4 (Figure 4 ), in whom but 2 platelet counts were made. 
(d) Bone marrow.

A summary of the differential bone marrow nucleated cell counts is presented in Table I. The polymorphonuclear and band form granulocytes remained about the same throughout, except in Cases Nos. 1 and 2 where a definite increase was seen after liver extract therapy.

More striking, however, is the change in megaloblast percentage following blood transfusions. No examination of the bone marrow was made in Case No: 1 before transfusions were begun, but undoubtedly megaloblasts were present in the quantity usual for pernicious anemia in relapse. Following transfusions they almost disappeared. The effect of transfusions in sharply decreasing the percentages of megaloblasts is seen in the differential counts of marrow cells obtained from Cases Nos. 2, 3, and 5, and is illustrated by the photomicrographs (Figures 6, 7). Furthermore, in Case No. 5, the megaloblasts reappeared during the $1 \frac{1}{2}$ months after transfusions were discontinued, at the end of which time the red cell

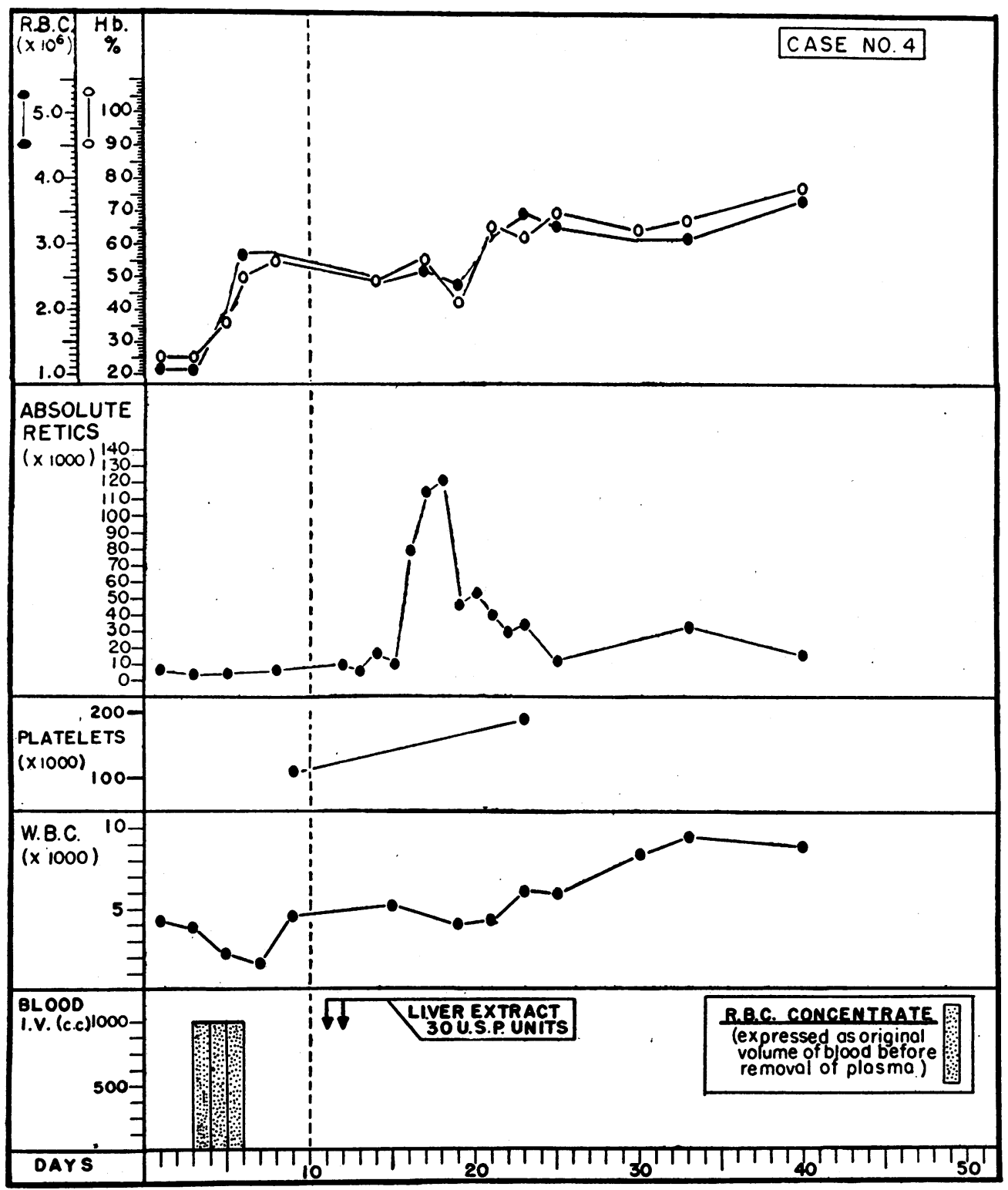

Fig. 4. CASE No. 4 


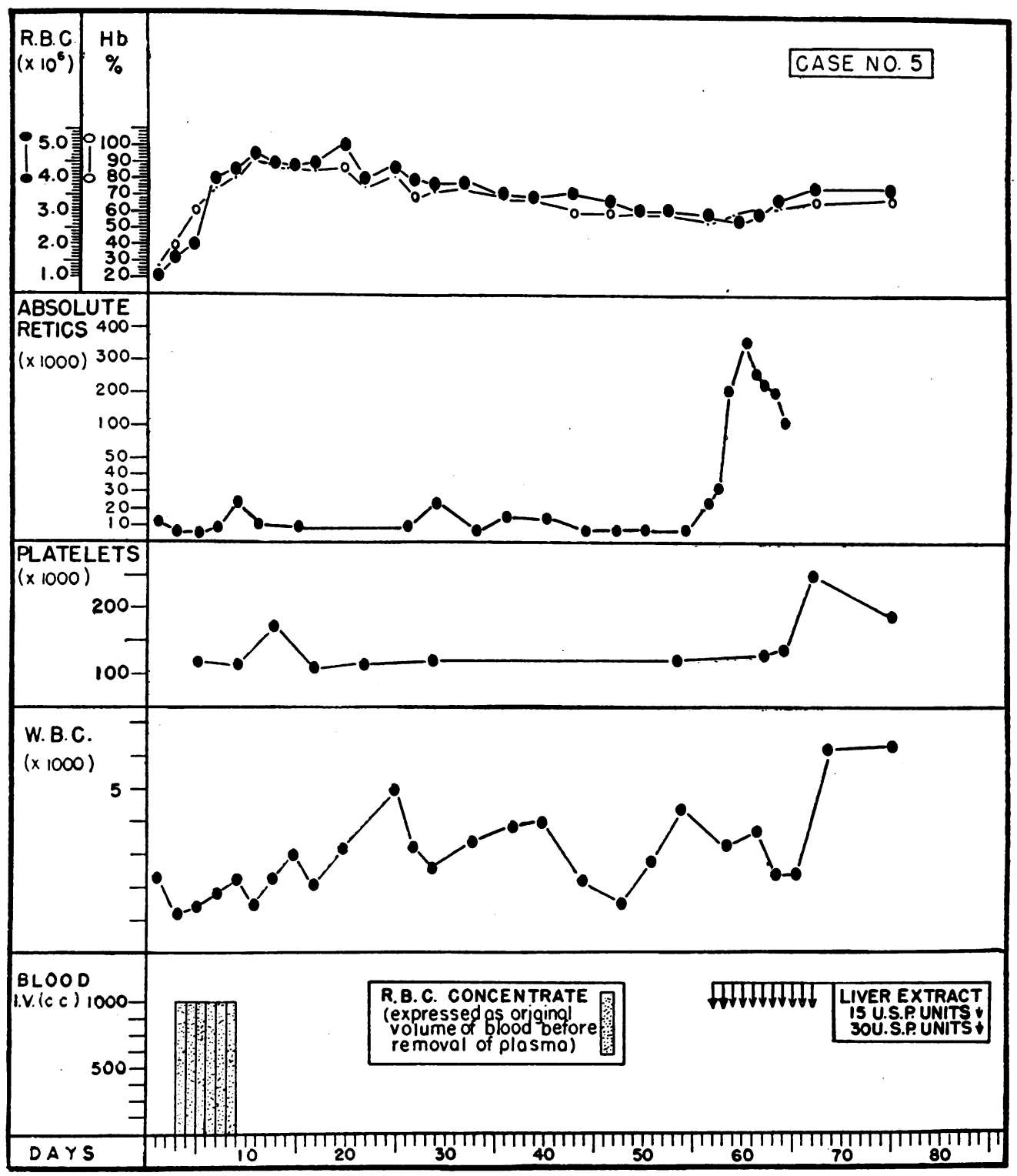

Fig. 5. Case No. 5

count had dropped from 5 to 3 million per cu. $\mathrm{mm}$.

\section{(e) Clinical course.}

Case No. 1, a 67-year-old white female, known to have had pernicious anemia in the past, suffered a relapse from failure to continue liver extract therapy. Before transfusions were begun she complained of weakness, anorexia, "indigestion," and a recurrence of nervous system symptoms. Inspection showed marked pallor, white hair, blue eyes, and a pale, smooth tongue. There was cardiac enlargement and dependent edema. Drowsiness with euphoria were the chief mental symptoms.

During the course of transfusions, the patient became even less active and responsive, and dozed most of the time. Her tongue became fiery red, with fissures, but no growth of papillae became evident. Her pallor was, however, replaced by normal skin color. This effect, which was presumably due simply to the return to normal hemoglobin concentration, was the only sign of clinical improvement on the 14th day, when liver extract was administered. On the 21st day, 7 days after liver extract was begun, the patient seemed for the first time definitely better. She appeared more alert, and took a more active interest in her surroundings. This improvement progressed rapidly, so that a week later she was up in a chair most of the day. The tongue had become less red, and papillae were beginning to appear. There was no significant change in 
symptoms or signs of spinal cord disease during the period of observation.

Case No. 2, a 45-year-old white male, was admitted in his first attack complaining of fatigue and weakness of several months' duration. He had had constipation and attacks of "indigestion," together with progressive anorexia. He had noticed numbness and tingling of his finger tips for about 1 week $\mathrm{He}$ was poorly nourished and pale; there was moderate loss of papillae on the tongue, especially along the margins. A definitely impaired vibration sense was present in both lower extremities. Mentally he was clear but a little lethargic. His pallor was replaced by normal color during the period of transfusion. However, although ambulatory since admission, his lethargy continued, and anorexia, "indigestion," and tongue changes likewise remained the same.

Beginning about 7 to 10 days after the administration of liver extract, there was a distinct change in the patient's condition. He became brighter and more cheerful. His appetite improved rapidly, and the tongue showed some regrowth of papillae. His paresthesiae disappeared in the course of about 2 weeks.

Case No. 3, a 59-year-old white female, in whom a diagnosis of pernicious anemia had been made 2 years previously, suffered a relapse after discontinuing liver therapy. Before blood transfusions were initiated, she complained of weakness, "indigestion," anorexia, and "gas" after meals. She noticed pounding in the head and had palpita-

TABLE I

Distribution of nucleated bone marrow cells

\begin{tabular}{|c|c|c|c|c|c|c|}
\hline Status & Day & $\begin{array}{l}\text { Polymorphs. } \\
\text { and bands }\end{array}$ & $\begin{array}{l}\text { Metamyelocytes } \\
\text { and myelocytes }\end{array}$ & Normoblasts & Erythroblasts & Megaloblasts \\
\hline $\begin{array}{l}\text { Case no. } 1 \\
\text { After transfusion } \\
\text { Before liver extract } \\
\text { R.B.C. } 4.70 \text { million } \\
\\
35 \text { days } \\
\text { After liver extract } \\
\text { R.B.C. } 5.1 \text { million }\end{array}$ & 14 & $\begin{array}{c}\text { per cent } \\
22 \\
40\end{array}$ & $\begin{array}{c}\text { per cent } \\
36 \\
24\end{array}$ & $\begin{array}{c}\text { per cent } \\
6 \\
10\end{array}$ & $\begin{array}{c}\text { per cent } \\
8 \\
6\end{array}$ & per cent \\
\hline $\begin{array}{l}\text { Case no. } 2 \\
\text { Before transfusion } \\
\text { R.B.C. } 1.03 \text { million } \\
\text { After transfusion } \\
\text { Before liver extract } \\
\text { R.B.C. } 5.17 \text { million } \\
\text { 15 days } \\
\text { After liver extract } \\
\text { R.B.C. } 4.30 \text { million }\end{array}$ & 1 & 25 & 22 & 7 & 10 & 25 \\
\hline $\begin{array}{l}\text { Case no. } 3 \\
\text { Before transfusion } \\
\text { R.B.C. } 1.18 \text { million } \\
\text { After transfusion } \\
\text { Before liver extract } \\
\text { R.B.C. } 3.17 \text { million } \\
\text { 6 days } \\
\text { After liver extract } \\
\text { R.B.C. } 2.94 \text { million }\end{array}$ & 3 & 16 & 18 & 11 & 15 & 28 \\
\hline $\begin{array}{l}\text { Case no. } 5 \\
\text { Before transfusion } \\
\text { R.B.C. } 1.02 \text { million } \\
\text { During transfusion }\end{array}$ & 2 & 21 & 8 & $\begin{array}{r}11 \\
0\end{array}$ & $\begin{array}{l}19 \\
10\end{array}$ & 21 \\
\hline $\begin{array}{l}\text { During transfusion } \\
\text { R.B.C. } 4.0 \text { million }\end{array}$ & 8 & 22 & 11 & 18 & 8 & 2 \\
\hline $\begin{array}{l}\text { End of transfusion } \\
\text { R.B.C. } 4.5 \text { million }\end{array}$ & 12 & 11 & 40 & 9 & 14 & 2 \\
\hline $\begin{array}{l}\text { No therapy } 46 \text { days } \\
\text { R.B.C. } 3.0 \text { million }\end{array}$ & 58 & 27 & 13 & 10 & 20 & 10 \\
\hline
\end{tabular}




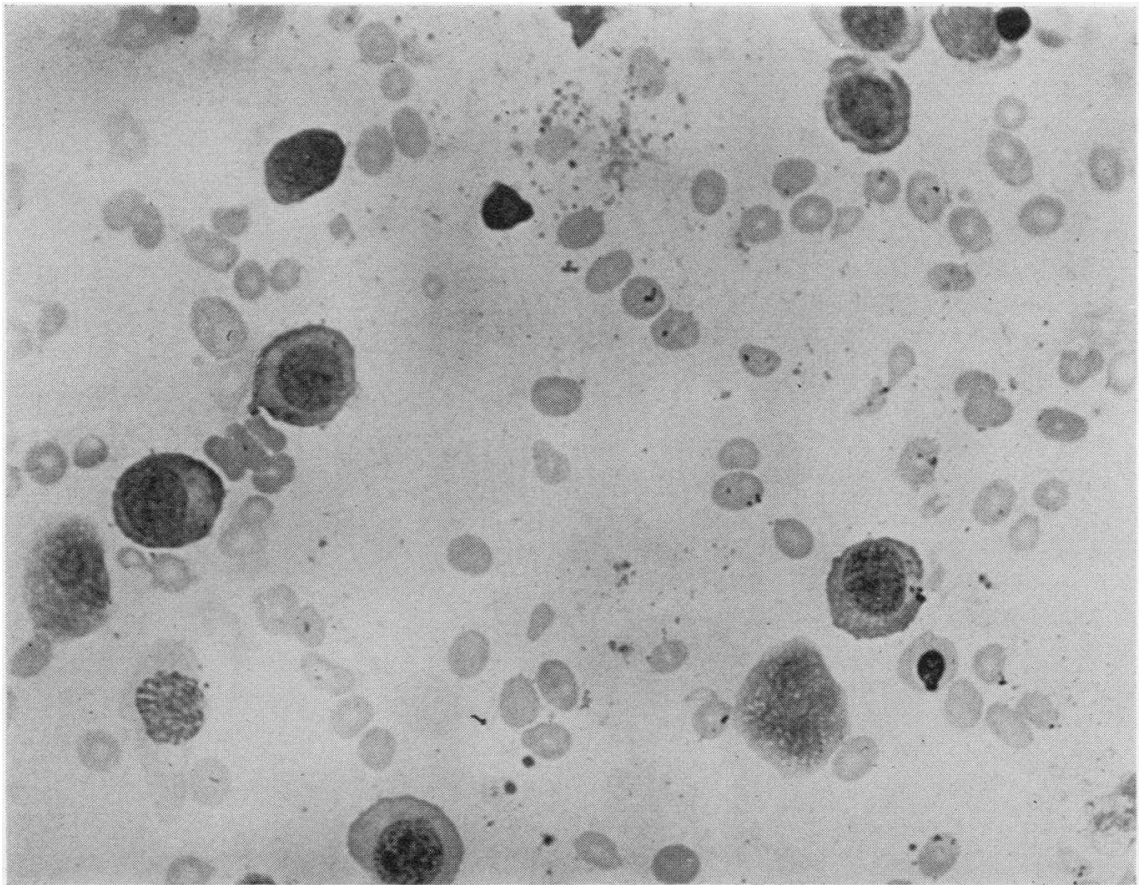

Fig. 6. Patient No. 2-Day 1. Before Transfusion

Red cell count, 1.03 million per cu. mm. Bone marrow film with large proportion of megaloblasts. (Wright's stain, oil immersion.)

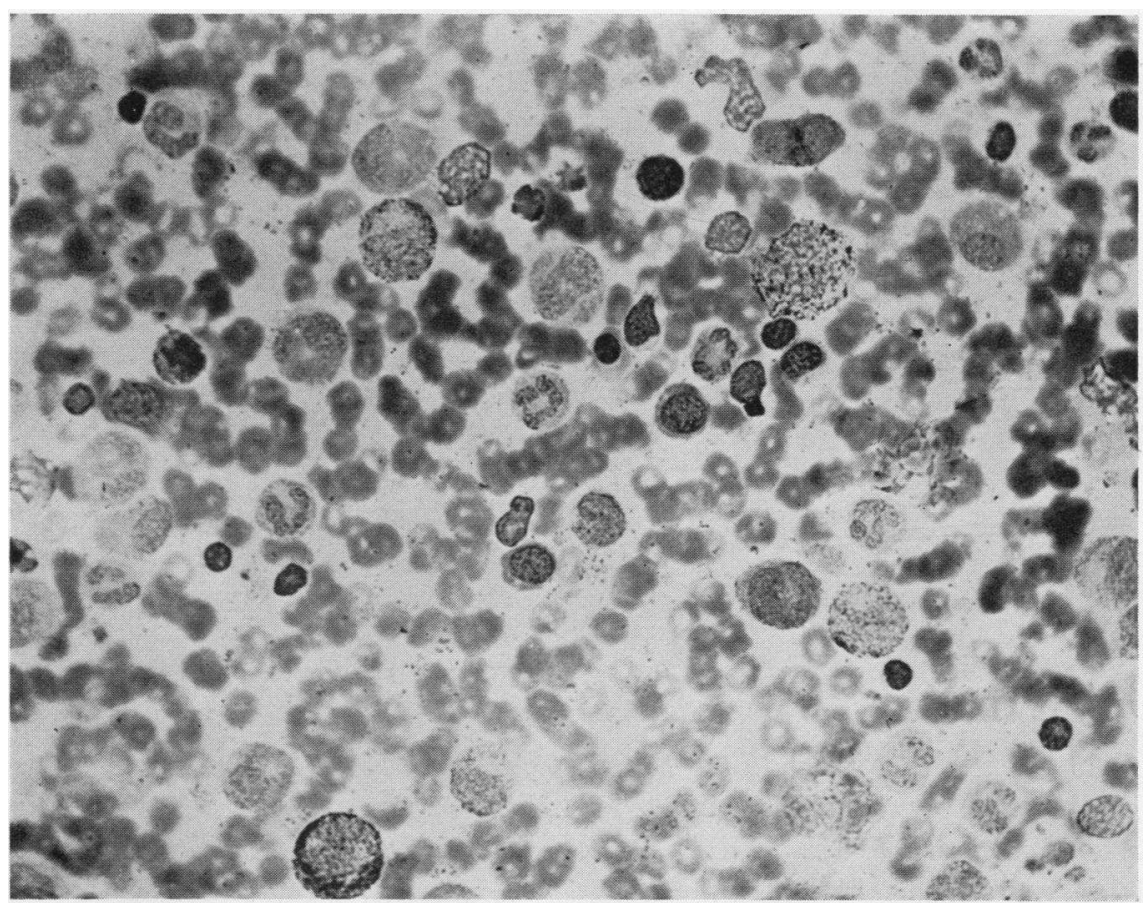

Fig. 7. Patient No. 2-Day 8. Transfusions Finished

Red cell count, 5.17 million per cu. $\mathrm{mm}$. Bone marrow film is relatively normal. Megaloblasts gone. (Wright's stain, oil immersion.) 
tion on exertion or on becoming disturbed emotionally. Her skin was waxy-yellow in appearance; the hair gray, the eyes blue, and the tongue papillae atrophic. Cardiac enlargement was moderate, but there was no dependent edema.

During and immediately after the course of red cell transfusions the patient noted disappearance of the head pounding and palpitation, and her color improved. There were no other subjective or objective changes. Soon after the reticulocyte peak, following liver extract administration, the patient began to improve markedly. Her appetite increased, gastro-intestinal symptoms diminished, and weakness gradually disappeared.

Case No. 4, a 73-year-old white male in whom a diagnosis of pernicious anemia had been made a year previously, later discontinued treatment with liver extract and was admitted after having collapsed. He confessed to having orthopnea and anginal pain on slight exertion. Marked pallor was evident on examination. The hair was gray, the eyes brown, and the tongue papillae moderately atrophic. No cardiac enlargement was observed, but dependent edema was present. The spleen was palpable at the left costal margin. There was no evidence of combined system disease.

Following red cell transfusions, orthopnea and anginal pain entirely disappeared, but anorexia and a listless facial expression continued. Following the administration of liver extract these also gradually disappeared, although not as dramatically as in the foregoing 3 patients.

Case No. 5, a 75-year-old white male without a previous history of pernicious anemia, on admission complained of increasing weakness, anorexia, and sore tongue of about 1 month's duration. On examination he was found to be markedly pale and emaciated, with an atrophic tongue. There was no cardiac enlargement nor dependent edema. No evidence of combined system disease was observed except for diminished vibratory sense in the lower extremities.

Following transfusions, his weakness decreased somewhat, but, in general, he was symptomatically the same for the $11 / 2$ months between blood transfusions and liver extract therapy. However, following the latter there was striking subjective and objective improvement. Especially remarkable was the regrowth of papillac on the tongue.

\section{DISCUSSION}

The administration of liver extract, in a decisively effective dose, to patients with pernicious anemia in relapse, produces certain constant physiological effects. After as little as 6 hours, the primitive megaloblasts of the bone marrow begin to decrease while a corresponding increase in the more mature cells takes place (15). Within 3 to 4 days the predominant erythroid cell is the normoblast. At about this time, the characteristic reticulocyte rise begins in the peripheral blood, and relief of anorexia with increase in strength and sense of well-being are experienced by the patient. The leukocytes, and especially the platelets, also increase in the peripheral blood. It is noteworthy that clinical improvement is often striking before any significant increase occurs in the levels of red cells and hemoglobin.

In none of the cases reported here, however, did transfusions modify the blood findings or clinical status, other than to abolish the anemia and the symptoms directly related to decreased hemoglobin concentration in the peripheral blood: pallor, palpitation, or angina. Anorexia, apathy, and digestive symptoms were not affected. Transfusions also failed to cause any increase in reticulocytes, or in leukocytes or platelets.

Although, in contrast to transfusions, liver extract therapy apparently caused remarkable clinical improvement and increases in leukocytes and platelets, the response of the reticulocytes was greatly modified by previous transfusions. Thus, reticulocyte response to liver extract therapy was absent in Case No. 1 with 5 million red cells per cu. mm., was slight in Case No. 2, whose red cells had dropped to about 4 million per cu. mm., was moderate in Cases No. 3 and 4 which were transfused to only 3 million per cu. mm., and was marked in Case No. 5, in which the red cells were allowed to drop from 5 to 3 million per cu. $\mathrm{mm}$. Thus, the reticulocyte response to liver extract was roughly inversely proportionate to the height of the artificially elevated red cell count and hemoglobin present at the time of its occurrence, and not to their low values before transfusions were given.

Such depression, or even failure, of the reticulocyte response to occur after liver extract therapy at artificially elevated red cell and hemoglobin levels could theoretically be the result of at least 2 effects of the transfusions. First, the abolition of the anemia, and consequently of the general accepted stimulus to red cell production, anemic anoxia. Second, the introduction of substances in the transfused normal blood equivalent in physiological action to liver extract, with resulting partial or complete inability of the patient to respond to a subsequent injection of liver extract.

Experiments on animals as well as observations in man have shown that the number of reticulocytes in the peripheral blood becomes decreased when the tissue oxygen tension is increased either 
by transfusions or by breathing high concentrations of oxygen (16 to 18 ). In pernicious anemia in relapse, the inverse relationship between height of reticulocyte response to liver extract and initial red cell (or hemoglobin) level (19) is well known. For red cell levels above 3.5 million per cu. mm., reticulocyte responses are slight or absent. This diminished response is conceivably due either to the relatively slight deficiency of the active principle of liver extract presumably existing in patients with such relatively high blood levels, or to the comparatively slight degree of anemic anoxia of their bone marrow. The present observations, in which for reasons given below it is probable that the existing deficiency of liver extract was not modified by the previous transfusions, suggest the latter explanation as the correct one.

As already indicated, the bone marrow was found to be strikingly altered in its morphology by transfusions given prior to the administration of liver extract. The percentage of typical megaloblasts in the bone marrow became sharply reduced within from 4 to 12 days after transfusions were begun, as the red cell counts rose in the peripheral blood. Because this effect is also so characteristic a sequel of the administration of liver extract, it is necessary to consider whether the transfusions of normal blood could have supplied, or have been equivalent to, the active principle of liver extract in these patients.

In numerous observations on patients with pernicious anemia, there has never been, in our experience, any detectable elevation of reticulocyte levels in the peripheral blood from transfusions of 500 , or sometimes $1,000 \mathrm{ml}$. of whole blood during control periods without other therapy. The negative effect of even larger transfusions upon reticulocytes is also convincingly shown in Cases Nos. 3 and 4 in which responses to the administration of liver extract followed shortly. This evidence, together with the failure of the white cells and platelets to increase, and especially the lack of significant clinical improvement, are in sharp contrast to the striking effects subsequently observed when liver extract was administered.

At first thought, it seems remarkable that the characteristic appearance of the bone marrow in pernicious anemia, which, since Peabody's (20) work, has been interpreted by many observers as evidence of a specific "maturation arrest," should be susceptible to rapid modification by transfusion alone. However, it is unlikely that all adult red cell production is at a standstill in untreated pernicious anemia. Consequently, if it is assumed that the megaloblasts are the precursors of more mature erythroblasts, and finally of adult reticulocytes and adult erythrocytes, the so-called "maturation arrest" must be a relative rather than an absolute state. Indeed, it has been suggested that the extensive, highly cellular and erythropoietically immature bone marrow picture in pernicious anemia is simply the response of that organ to the anemia resulting from a hemolytic process which destroys erythrocytes, especially reticulocytes, before they leave the marrow (5). Certainly the greatly increased output of urobilinogen $(21,22)$ and of coproporphyrin Type I (7) in the stools find their analogy in the classical hemolytic anemias, such as congenital hemolytic jaundice. Moreover, in these undisputed hemolytic anemias the bone marrow, though it does not actually contain megaloblasts, is extensive and highly cellular, and the dominant erythroid cells are normoblasts or even younger erythroblasts $(9,10)$. In animal experiments Steele ( 8 ) has shown that the immaturity of the erythroid cells of the bone marrow increases with the severity of the anemia produced by blood loss or destruction. Consequently, whether pernicious anemia is an anemia caused by diminished production or by increased destruction of red cells, the stimulus to red cell production will be decreased if the severity of the anemic anoxia is diminished artificially by blood transfusions which do nothing more than raise the hemoglobin concentration in the blood perfusing the bone marrow. Thus, if the development of megaloblasts in the bone marrow in pernicious anemia is partly proportional to the degree of anemic anoxia of the bone marrow, transfusions of blood should have the effect of causing the megaloblasts to diminish in number. The rapid disappearance of the megaloblasts in the bone marrow as a result of their probable conversion to move mature forms as suggested by Schwartz (23) is further evidence against any specific genetic origin of these cells.

The available evidence, however, suggests that both the anoxia of severe anemia and a deficiency of an essential factor for maturation are involved in the production of the classical bone marrow picture in pernicious anemia. According to 
to Davidson, Davis, and Innes (15) the administration of liver extract may initiate in 6, and complete in 72, hours the disappearance of the megaloblasts from the bone marrow. This result clearly precedes any significant rise in red cell and hemoglobin values in the peripheral blood. Therefore, it is highly unlikely that the disappearance of the megaloblasts is entirely secondary to a decrease of bone marrow anoxia, as a result of an increased hemoglobin concentration in the blood perfusing the bone marrow. Consequently, the transformation of the megaloblasts cannot be considered to result wholly from the cessation of a hemolytic process, or from increased blood production. Instead, the administration of liver extract must have a direct effect on the rate of maturation of the erythroid cells. It should be understood, however, that this evidence of relative maturation arrest in the formation of megaloblasts does not exclude a hemolytic process as contributory to the anemia, nor does it deny the possibility that liver extract therapy also acts by abolishing a process destructive to reticulocytes, leukocytes, and platelets.

Because deficiency of the active principle of liver extract, as well as the severity of the anemia, can apparently cause immaturity of the erythroid cells of the bone marrow, there is nothing paradoxical in the observation that both liver extract administration and transfusions tend to diminish the megaloblasts in the bone marrow in pernicious anemia. In other types of equally severe anemias, however, immaturity of the erythroid cells does not proceed to the formation of numerous megaloblasts $(9,10)$. Consequently, it is logical to assume that the anoxia caused by severe anemia is, by itself, insufficient to produce erythroid cells more immature than erythroblasts, unless an additional impediment to the development of their precursors is created by a nutritional deficiency of the active principle of liver extract. Certainly, as was shown by the failure of transfusions to cause the leukocyte and platelet counts to rise, the establishment of normal levels of these elements in the peripheral blood stream also requires the administration of an active principle of liver extract. The close dependency of the red cell, leukocyte, and platelet responses in pernicious anemia upon a common nutritional factor in liver extract is further attested by the similar responses of these blood elements to pure synthetic $L$. casei factor $(3,4)$.

\section{SUMMARY AND CONCLUSIONS}

1. Rapidly repeated transfusions of blood given to 5 patients with pernicious anemia in relapse, with rises to normal red cell values in 3, failed to produce the striking clinical improvement usually seen following the administration of liver extract, nor did the white cell or platelet counts increase. Thus, as in other nutritional deficiency diseases, much of the clinical improvement in pernicious anemia occurring promptly after administration of the missing nutritional element is presumably a result of specific effects on general cell metabolism, rather than a result of any change in blood values.

2. The previously observed negative effect of transfusions of usual amounts of blood on reticulocytes, leukocytes, and platelets, was shown to extend to larger amounts of blood. Clearly, transfusions do not have hematopoetic effects comparable to those of liver extract administration.

3. Subsequent intramuscular liver extract therapy was followed by rapid clinical improvement, but reticulocyte responses occurred only in those patients with red cell counts below 5 million per cu. $\mathrm{mm}$. A return to normal values of the white cells and platelets was observed at all red cell levels. Thus, liver extract therapy produces a reticulocyte response only when anemic anoxia, the normal stimulus for red cell production, is present; but the responses of white cell and platelets are independent of the degree of anemia.

4. Following the blood transfusions, but prior to the liver extract therapy, the bone marrow megaloblasts characteristic of pernicious anemia disappeared. Others have shown that liver extract therapy also causes these cells to disappear before any significant change occurs in the red cell or hemoglobin levels of the blood. This proves that a state of "maturation arrest," due to a nutritional deficiency, exists. The effect of transfusions suggests that this state is relative rather than absolute, and that it can be affected by an artificial decrease in the degree of bone marrow anoxia.

5. Although relative "maturation arrest" of the bone marrow megaloblasts in pernicious anemia appears to result in part from a deficiency of the active principle of liver extract, this does not exclude increased blood destruction as a contribut- 
ing, or even as a dominant, factor in causing the anemia.

We are indebted to Miss Geneva A. Daland for interpretation of bone marrow films; to the Surgical Services, Boston City Hospital, for performing sternal marrow biopsies; and to the Resident Staff of the Second and Fourth Medical Services, Boston City Hospital, for their cooperation in caring for the patients during this study.

\section{BIBLIOGRAPHY}

1. Minot, G. R., and Murphy, W. P., A diet rich in liver in the treatment of pernicious anemia; study of one hundred and five cases. J. A. M. A., 1927, 89, 759.

2. Sturgis, C. C., and Isaacs, R., Desiccated stomach in the treatment of pernicious anemia. J. A. M. A., 1929, 93, 747.

3. Moore, C. V., Bierbaum, O. S., Welch, A. D., and Wright, L. D., The activity of synthetic lactobacillus casei factor ("Folic acid") as an anti-pernicious anemia substance. I. Observations on four patients: two with Addisonian pernicious anemia, one with non-tropical sprue, and one with pernicious anemia of pregnancy. J. Lab. and Clin. Med., 1945, 30, 1056.

4. Vilter, C. F., Spies, T. D., and Koch, M. B., Further studies on Folic acid in the treatment of macrocytic anemia. South. Med. J., 1945, 38, 781.

5. Dock, W., The importance of hemolysis in the pathogenesis of macrocytic anemia. Medical Papers dedicated to Dr. Henry A. Christian, p. 545 to 558, Williams and Wilkins Co., Baltimore, 1936.

6. Dock, W., The ebb and flow of theories about pernicious anemia. Am. J. Clin. Path., 1938, 8, 620.

7. Dobriner, K., and Rhoads, C. P., The metabolism of blood pigments in pernicious anemia. J. Clin. Invest., 1938, 17, 95.

8. Steele, B. F., The effects of blood loss and blood destruction upon the erythroid cells in the bone marrow of rabbits. J. Exper. Med., 1933, 57, 881.

9. Tötterman, G., Das Knochenmark bei hämolytischen Ikterus mit einem Beitrag zur Frage nach der Natur der Megaloblasten. Acta Med. Scand., 1936, 90, 527.
10. Dameshek, W., and Schwartz, S. O., Acute hemolytic anemia (acquired hemolytic icterus, acute type). Medicine, 1940, 19, 231.

11. Wintrobe, M. M., Clinical Hematology, 703 pp., Philadelphia, Lea and Febiger, 1942.

12. Pohle, F. J., Blood platelet count in relation to the menstrual cycle in normal women. Am. J. M. Sc., 1939, 197, 40.

13. Murphy, W. P., An easy method of estimating the amount of jaundice by means of the blood serum, Boston M. and S. J., 1926, 194, 297.

14. Turkel, H., and Bethell, F. H., Biopsy of the bone marrow performed by a new and simple instrument. J. Lab. and Clin. Med., 1943, 28, 1246.

15. Davidson, L. S. P., Davis, L. J., and Innes, J., The effect of liver therapy on erythropoiesis as observed by serial sternal punctures in twelve cases of pernicious anemia. Quart. J. Med., 1942, 11, 19.

16. Campbell, J. A., Prolonged alterations of oxygen pressure in the inspired air with special reference to tissue oxygen tension, tissue carbon dioxide tension, and hemoglobin. J. Physiol., 1927, 62, 211.

17. Boycott, A. E., and Oakley, C. L., The regulation of marrow activity: experiments on blood transfusion and on the influence of atmospheres rich in oxygen. J. Path. and Bact., 1933, 36, 205.

18. Reinhard, E. H., Moore, C. V., Dubach, R., and Wade, L. J., Depressant effects of high concentrations of inspired oxygen in erythrocytogenesis. Observations on patients with sickle cell anemia with a description of the observed toxic manifestations of oxygen. J. Clin. Invest., 1944, 23, 682.

19. Minot, G. R., Murphy, W. P., and Stetson, R. P., The response of the reticulocytes to liver therapy, particularly in pernicious anemia. Am. J. M. Sc., 1928, 175, 581.

20. Peabody, F. W., The pathology of the bone marrow in pernicious anemia. Am. J. Path., 1927, 3, 179.

21. Eppinger, H., and Charnas, D., Was lehren uns quantitative Urobilinbestimmungen im Stuhl? Ztschr. f. klin. Med., 1913, 78, 387.

22. Watson, C. J., Studies of Urobilinogen. III. The per diem excretion of urobilinogen in the common forms of jaundice and liver disease. Arch. Int. Med., 1937, 59, 206.

23. Schwarz, E., The nature of the megaloblast. Hematol. Monographs, 1946, 1, 3 . 